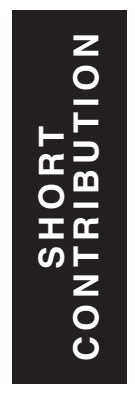

\title{
New stratigraphic markers in the late Pleistocene Palouse loess: novel fossil gastropods, absolute age constraints and non-aeolian facies
}

\author{
PATRICK K. SPENCER and ANGELA N. KNAPP ${ }^{1}$ \\ Department of Geology, Whitman College, 345 Boyer Avenue, Walla Walla, WA 99362, USA \\ (E-mail: spencerp@whitman.edu) \\ Associate Editor - Nick Eyles
}

\begin{abstract}
Four stratigraphic sections in the southern part of the Columbia Basin preserve a sequence of aeolian and non-aeolian sediments ranging in age from 9.43 to $>47 \cdot 0{ }^{14} \mathrm{C}$ ka based on accelerator mass spectrometry radiocarbon dating of fossil molluscs, geochemistry of Cascade Mountain-sourced tephra and association with formally recognized pedostratigraphic units (the Washtucna and Old Maid Coulee soils). Study sections are interpreted as representing concurrent deposition of loess and distal Missoula Flood rhythmites in valleys tributary to main drainages backflooded during the Missoula Floods, and formation of carbonate and iron-rich soils. Sediments belong to the formally recognized L-1 and L-2 loess units established for the Palouse loess, which were deposited in the Columbia Basin subsequent to events of glacial outburst flooding. Sediments associated with the Mount Saint Helens set S and set C tephras in the study sections preserve a fauna of five species of gastropod mollusc which have not been reported previously from sediments of late Pleistocene age in the Palouse region. The fossils comprise two distinct faunules stratigraphically separated by the Mount Saint Helens So tephra. Accelerator mass spectrometry radiocarbon dating of the fossils collected above the tephra in two of the sections yielded ages of $12 \cdot 48 \pm 0 \cdot 06$ and $9 \cdot 43 \pm 0 \cdot 05{ }^{14} \mathrm{C}$ kyr. These ages suggest that independent determinations of the $13 \cdot 35{ }^{14} \mathrm{C} \mathrm{kyr}$ age of the So tephra in other areas where Missoula Flood sediments are preserved are probably accurate, and help to refine the age of the latest events in the most recent sequence of catastrophic glacial outburst flooding.
\end{abstract}

Keywords Loess, Missoula Floods, mollusc, Mount Saint Helens, Pleistocene, soils.

\section{INTRODUCTION}

Regions sculpted by Quaternary glaciations, including North America, commonly have covers of thick, undifferentiated loess deposits left behind as signatures of these events. These massive loess deposits can be a few to over $100 \mathrm{~m}$ thick, making it difficult to discern both the relative chronology and absolute age of the sequences. While typical stratigraphic indicators such as fossil vertebrates are abundant in the Pleistocene Palouse loess of Washington State, they are uncommon in other Quaternary units of the north-western USA, such as the Missoula Flood deposits (Rensberger et al., 1984; Spencer, 1989). Field work conducted for the present

\footnotetext{
${ }^{1}$ Present address: Marine and Atmospheric Chemistry, Rosenstiel School of Marine and Atmospheric Science, University of Miami, 4600 Rickenbacker Causeway, Miami, FL 33149, USA.
} 
report indicates that previously undocumented fossil terrestrial gastropods are common in certain facies of the Palouse loess, providing another tool with which to identify and correlate geographically discrete loess outcrops. This report provides age, stratigraphic and sedimentological data and interpretations for four study sections in southern exposures of the Palouse loess and documents the stratigraphic and sedimentological context for five species of gastropod mollusc. In addition, absolute age constraints are established for the gastropodbearing intervals in the McFeely Road and Piper Canyon sections (Fig. 1) based on accelerator mass spectrometry (AMS) radiocarbon dating of shell material. Finally, the relationship between the study sections and the late Pleistocene slackwater deposits generated by the Missoula Floods (the Touchet Beds) are interpreted.
The sections studied are located approximately $25 \mathrm{~km}$ north of Walla Walla, Washington, and are exposed in shallow, ephemeral stream valleys tributary to the Touchet River, and on the drainage divide between the Touchet River and Eureka Flat to the north. Location of study sections and physiographic features mentioned in the text are shown in Fig. 1.

\section{REGIONAL GEOLOGICAL SETTING}

The bedrock of the Palouse Hills of south-eastern Washington comprises a thick sequence of basalt flows assigned to the Miocene Columbia River Basalt Group (CRBG), which is overlain by, and interbedded with, several lithostratigraphic units. The Ellensburg Formation (Miocene), exposed in the western portion of the Columbia Plateau,

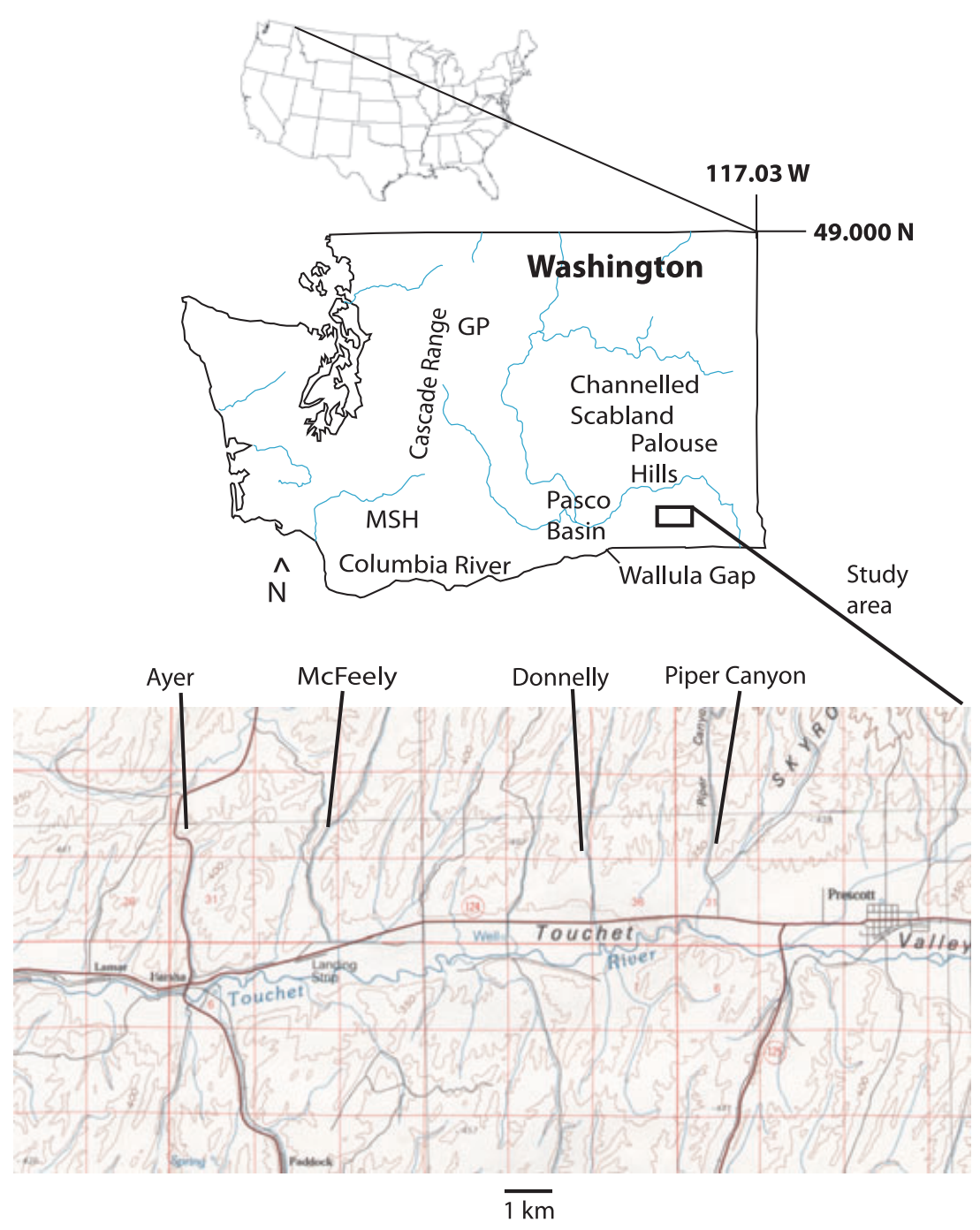

Fig. 1. Index map of Washington state and study area showing the locations of the study sections in central Walla Walla County and physiographic features mentioned in the text. MSH, Mount St Helens; GP, Glacier Peak. 
comprises a sequence of tuffaceous fluvial and lacustrine sediments derived from the rising Cascade Mountains, which was distributed eastward across the developing Yakima fold belt (Smith, 1988). The Miocene to Pliocene Ringold Formation overlies the CRBG in the Pasco Basin (Fig. 1) and is interpreted as representing deposition by rivers draining the Rocky Mountains (Lindsey, 1990).

The CRBG, the Ellensburg Formation and the Ringold Formation are overlain by an extensive aeolian silt and sand deposit informally known as the Palouse loess. The age of the Palouse loess varies widely within the Pleistocene and Holocene. Cascade-sourced tephras and palaeomagnetism provide absolute and relative age markers in the unit; distinctive carbonate palaeosols (for example, the Washtucna and Old Maid Coulee soils of McDonald \& Busacca, 1992; Busacca \& McDonald, 1994) are useful physical markers. Interbedded with the Palouse loess are at least four, and perhaps as many as six, distinct sedimentary sequences representing periods of catastrophic glacial outburst flooding (McDonald \& Busacca, 1988, 1992; Busacca \& McDonald, 1994; Bjornstadt et al., 2001; Spencer \& Jaffee, 2002). The most recent flood sequence originated at glacial Lake Missoula in western Montana and is known as the Missoula Floods; earlier flood sequences are of unknown origin. Flood sequences are distinguishable from each other by bounding unconformities (Spencer \& Jaffee, 2002); sedimentary textures and structures distinguish them from the associated loess.

The Palouse loess comprises a thick and monotonous sequence of fine-grained aeolian sediment derived from the Pasco Basin to the west of the Palouse region (McDonald \& Busacca, 1992; Busacca \& McDonald, 1994). Sites studied for this report show that, in central Walla Walla County, the loess is associated with sediment deposited by non-aeolian processes; stratification, graded bedding and variations in texture indicate aqueous deposition for these occurrences.

\section{STRATIGRAPHIC AND PALAEONTOLOGICAL FRAMEWORK FOR THE PALOUSE LOESS}

Rensberger et al. (1984) established a biostratigraphic framework for the Palouse loess and provided ecological and taxonomic data, based on the occurrence of small mammal fossils in a section spanning at least the last $40 \mathrm{kyr}$ and perhaps as much as the last $100 \mathrm{kyr}$. Busacca et al. (1992) and McDonald \& Busacca (1992) developed a correlation scheme for outcrops of younger loess in the southern Channelled Scabland (Fig. 1) based on stratigraphic and sedimentological features, including stratigraphic sequence, soil development and tephra chronology. Busacca \& McDonald (1994) recognized and named two loess units: the L-1 [stratigraphically above the Mount St Helens (MSH) set $\mathrm{S}$ tephra] and L-2 (stratigraphically below the $\mathrm{MSH}$ set $\mathrm{S}$, and including the $\mathrm{MSH}$ set $\mathrm{C}$ tephra near its base). The position of the loess units was defined further with respect to distinctive carbonate palaeosols including the Washtucna soil, which occurs beneath the MSH set $S$ tephra, the Old Maid Coulee soil, which contains the MSH set C tephra, and the Devil's Canyon soil, which forms the lower boundary of the L-2 loess unit.

\section{STRATIGRAPHIC AND SEDIMENTOLOGICAL CONTEXT OF STUDY SECTIONS}

\section{Ayer Road section}

The Ayer Road section (Figs 1 and 2) comprises about $15 \mathrm{~m}$ of massive silt and fine sand with multiple horizons of carbonate soil and three recognizable tephras, exposed at an elevation of about $385 \mathrm{~m}$. Based on the identity of soils and associated tephras, the Ayer Road section includes the L-1 and L-2 loess of Busacca \& McDonald (1994), as well as the upper portion of an older, unnamed silt unit.

One of the soils is identified as the Washtucna soil (of McDonald \& Busacca, 1992) based on distinctive morphological features, such as stage of soil development and close association of two stacked soils, and its stratigraphic position above a tephra identified as an MSH set C and below a tephra identified as an MSH set S (see Table 1 for tephra glass compositions). A second soil is identified as the Old Maid Coulee soil by its association with the MSH set C tephra. A third tephra consisting of a dark grey, fine-grained, indistinct layer occurs beneath the MSH set C. The distinctive physical appearance and stratigraphic position of this tephra beneath the set C tephra and the Old Maid Coulee soil make it a useful marker. This lower tephra unit (the KP-1C 


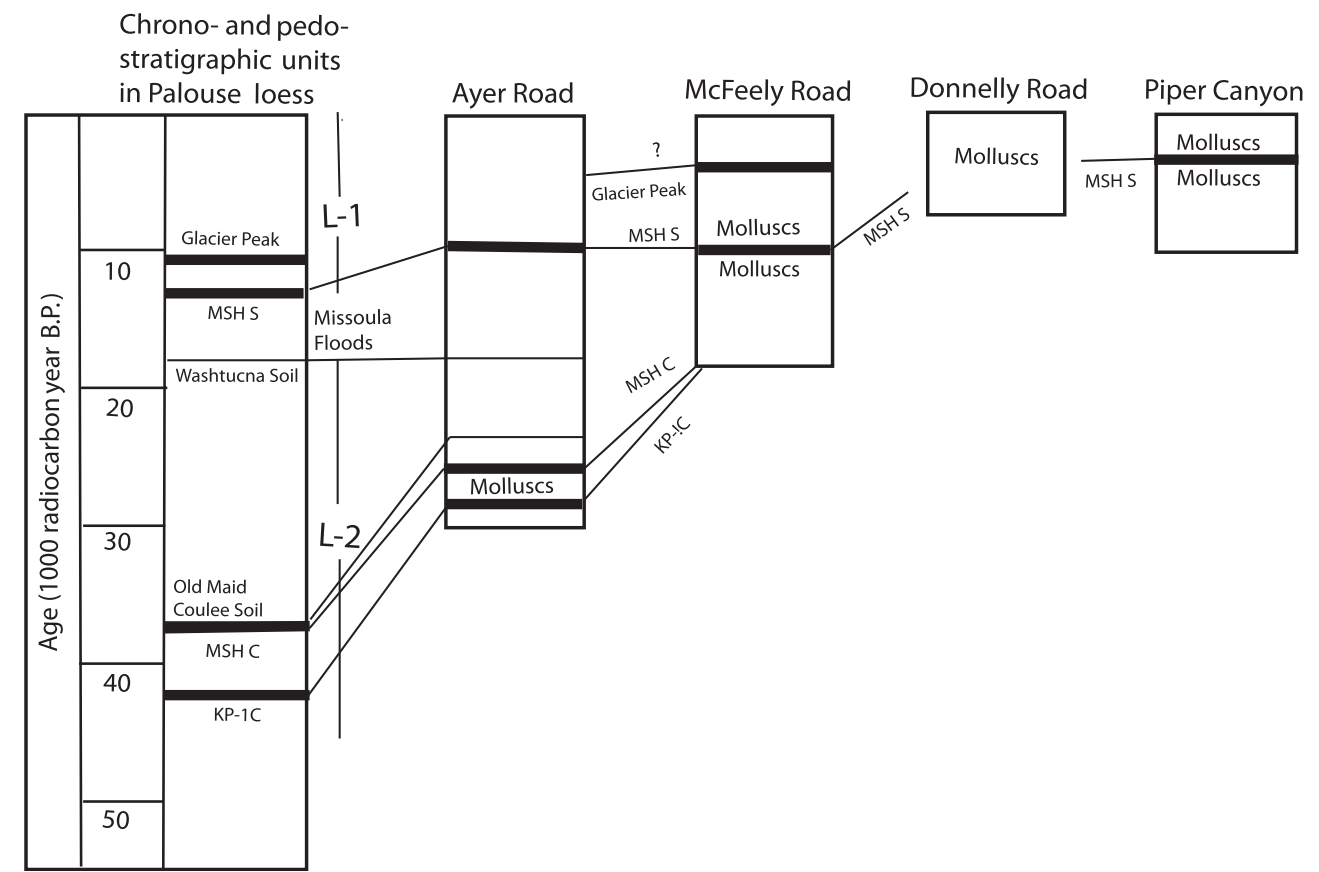

Fig. 2. Correlation of study sections in Walla Walla County with recognized pedostratigraphic and tephra units in the central Columbia Plateau (Busacca \& McDonald, 1994). MSH, Mount St Helens. No scale intended.

Table 1. Oxide compositions of glass in tephras from study sections (SD in parentheses).

\begin{tabular}{|c|c|c|c|c|c|}
\hline Oxide & McFeely \#1 & McFeely \#2 & Piper Canyon & Ayer Road \#1 & Ayer Road \#2 \\
\hline $\mathrm{SiO}_{2}$ & $77 \cdot 45(0 \cdot 62)$ & $77 \cdot 43(0 \cdot 37)$ & $77 \cdot 22(0 \cdot 41)$ & $76 \cdot 35(0 \cdot 22)$ & $76 \cdot 98(0 \cdot 20)$ \\
\hline $\mathrm{Al}_{2} \mathrm{O}_{3}$ & $13 \cdot 18(0 \cdot 39)$ & $12 \cdot 74(0 \cdot 19)$ & $13 \cdot 25(0 \cdot 27)$ & $13 \cdot 72(0 \cdot 08)$ & $13 \cdot 69(0 \cdot 09)$ \\
\hline $\mathrm{Fe}_{2} \mathrm{O}_{3}$ & $1 \cdot 23(0 \cdot 08)$ & $1 \cdot 15(0 \cdot 09)$ & $1 \cdot 24(0 \cdot 06)$ & $1 \cdot 38(0 \cdot 08)$ & $1 \cdot 04(0 \cdot 08)$ \\
\hline $\mathrm{TiO}_{2}$ & $0 \cdot 16(0 \cdot 02)$ & $0 \cdot 21(0 \cdot 03)$ & $0 \cdot 17(0 \cdot 02)$ & $0 \cdot 14(0 \cdot 02)$ & $0 \cdot 10(0 \cdot 04)$ \\
\hline $\mathrm{Na}_{2} \mathrm{O}$ & $3 \cdot 85(0 \cdot 13)$ & $3 \cdot 51(0 \cdot 14)$ & $3 \cdot 98(0 \cdot 11)$ & $4 \cdot 10(0 \cdot 12)$ & $3 \cdot 85(0 \cdot 11)$ \\
\hline $\mathrm{K}_{2} \mathrm{O}$ & $2 \cdot 29(0 \cdot 09)$ & $3 \cdot 13(0 \cdot 19)$ & $2 \cdot 32(0 \cdot 07)$ & $2 \cdot 25(0 \cdot 05)$ & $2 \cdot 38(0 \cdot 09)$ \\
\hline $\mathrm{MgO}$ & $0 \cdot 29(0 \cdot 03)$ & $0 \cdot 27(0 \cdot 03)$ & $0 \cdot 28(0 \cdot 03)$ & $0 \cdot 32(0 \cdot 03)$ & $0 \cdot 26(0 \cdot 03)$ \\
\hline $\mathrm{CaO}$ & $1 \cdot 41(0 \cdot 18)$ & $1 \cdot 34(0 \cdot 14)$ & $1 \cdot 45(0 \cdot 09)$ & $1 \cdot 65(0 \cdot 05)$ & $1 \cdot 65(0 \cdot 09)$ \\
\hline $\mathrm{Cl}$ & $0 \cdot 11(0 \cdot 02)$ & $0 \cdot 19(0 \cdot 02)$ & $0 \cdot 09(0 \cdot 02)$ & $0 \cdot 09(0 \cdot 02)$ & $0 \cdot 06(0 \cdot 02)$ \\
\hline SC & 0.973 & 0.970 & 0.98 & $0 \cdot 986$ & 0.98 \\
\hline No. shards & 17 & 16 & 16 & 26 & 22 \\
\hline Source & MSH So & GP & MSH So & MSH So & MSH C \\
\hline Age & 13350 & 11600 & 13350 & 13350 & 47000 \\
\hline
\end{tabular}

MSH, Mount St Helens; GP, Glacier Peak. Age given in ${ }^{14} \mathrm{C}$ yr вр (MSH set S: Clague et al., 2003; MSH set C: Negrini et al., 2000; GP: Kuehn et al., 2009). Similarity coefficient after Borchardt et al. (1972).

tephra) is of unknown source and age (Busacca et al., 1992).

The Ayer Road section is interpreted as a succession of loess, the deposition of which periodically slowed down or ceased and allowed development of calcic B soil horizons. According to Busacca \& McDonald (1994), the L-1 and L-2 loess units had a source in catastrophic outburst flood deposits of late Wisconsinan (Missoula Flood) and middle or early Wisconsinan age, respectively. These loess units originated as slackwater sediments deposited in the Pasco Basin and Walla Walla Valley.

Fossil gastropod molluscs in the Ayer Road section occur in a mica-rich interval below the Old Maid Coulee soil and the MSH set C tephra, near the base of the L-2 loess unit (Busacca \& McDonald, 1994). The molluscan fauna here consists of abundant specimens of the genus Columella Westerlund. The occurrence of the fossils in an interval of structureless silt interpreted as loess raises the possibility that the 
fossils were transported to this locality by aeolian processes. However, most of the specimens are whole and appear to be unabraded (Fig. 3B).

Ecological preferences of living species of $\mathrm{Col}$ umella suggest that the fossils inhabited cool, moist habitats on the edges of low-lying swamps or ponds (Taft, 1961). Modern topography, as well as the geometry of the Washtucna and Old Maid Coulee soils, which mirror ancient topography, suggests that the Ayer Road section was a topographic high when the sediments accumulated. The fossil occurrence in aeolian sediment on a topographic high, in association with a calcic B-horizon soil is thus inconsistent with modern ecological preferences, lending support to the idea of a wind-transported fauna.

\section{McFeely Road section}

Sedimentology of the McFeely Road section (Figs 1 and 2) is more complex than that of the Ayer Road site. The section is about $5 \mathrm{~m}$ thick and comprises rhythmically bedded finegrained sediment with oxidized, root cast-bearing horizons and coarse-grained, small-channel deposits, containing basalt and caliche fragments, which are exposed at an elevation of about $311 \mathrm{~m}$. Overlying these sediments are fine-grained sand and silt deposits containing a well-developed carbonate palaeosol. The base of the exposed section at McFeely Road comprises rhythmically deposited fine-grained sediments. The lower contact of the McFeely Road section is not exposed. However, a few tens of metres north of the study section, rocks belonging to the CRBG are exposed in road cuts. It is likely that the base of the stratified sediments exposed in the road cut is close to the sediment/basalt contact. Two tephras (Fig. 2) occur in the McFeely Road section. The lowermost tephra is identified as the MSH So, which occurs just below the base of a mottled brown and grey, partially oxidized interval with abundant root casts overlying a set of graded beds. The upper tephra, identified as Glacier Peak, occurs within the fine-grained sediment near the top of the section.

The McFeely Road outcrop is interpreted as representing sediment that accumulated as a result of repetitive processes in an aqueous environment. Cyclicity is demonstrated in the thinly bedded silts and clays comprising the lower and middle portion of the section. The rhythmically bedded sands, silts and clays in the lower and middle parts of the section are capped by a $1 \mathrm{~m}$ thick unit of massive silt and clay interpreted as a soil zone. The soil is characterized by the presence of clay-rich sediment containing root casts and veinlets of oxidized material; it is morphologically similar to hydromorphic soils, as described by Duchaufour (1982), which are reduced as a result of long-term
Fig. 3. Representative gastropod molluscs from Ayer Road, McFeely Road, Piper Canyon and Donnelly Road study sections. (A) Striatura; (B) Columella; (C) Succinea; (D) Vallonia; (E) Vertigo. The scale to the right of each specimen is in millimetres.

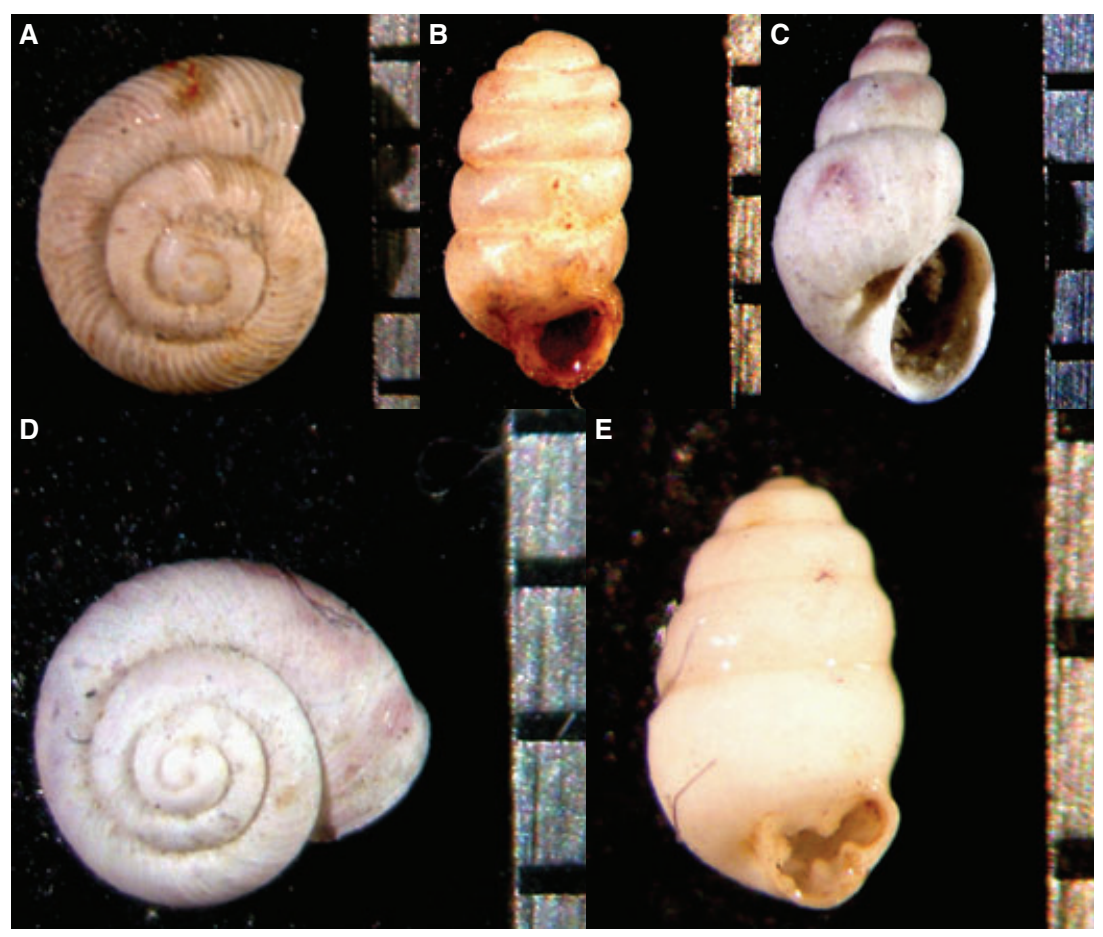


waterlogging and absence of oxygen, but may contain segregated iron oxides resulting from aeration by root activity.

Soil in the McFeely Road section developed under moist, semi-saturated conditions, in contrast to soils in the Ayer Road section, which are calcium carbonate-rich caliche soils that formed under drier, well-drained conditions. Absence of stratification in the McFeely Road soil zone is indicative of intense bioturbation, consistent with the presence of abundant root casts. The development of a hydromorphic soil zone indicates a low rate, or periodic process of sediment deposition, and aeration of the surface sediment under saturated conditions; it may indicate infilling of a pond with sediment and concurrent growth of vegetation on the boggy soil surface. The McFeely Road section is fossiliferous, yielding abundant mollusc and rare, unidentifiable small mammal fossils. The molluscan fauna (Fig. 3) comprises five genera of gastropods, including Columella Westerlund, Vertigo Muller, Succinea Drapernaud, Striatura Morse and Vallonia Sterki.

The McFeely Road outcrop is interpreted as representing distal late-Missoula Flood slackwater deposits and a minor impoundment in an ephemeral stream valley that received periodic sediment input. Rhythmically graded beds of fine-grained sediment represent short-term fluctuation in depositional energy; it will be shown that these rhythmically bedded sediments are associated with the late Wisconsinan Missoula Floods. Capping this interval, an oxidized and bioturbated soil with a well-developed fauna of terrestrial gastropods suggests periods of little or no sediment input, persistence of swampy conditions, growth of vegetation and soil formation.

\section{Donnelly Road section}

The Donnelly Road section is exposed poorly in a $1 \mathrm{~m}$ high roadcut between McFeely Road and Piper Canyon, at an elevation of 310 to $315 \mathrm{~m}$ (Figs 1 and 2). The sediments are similar in appearance and texture to the exposures in Piper Canyon. However, there are no marker tephra horizons in the Donnelly Road exposure. A single specimen of the gastropod genus Succinea has been recovered from the Donnelly Road section.

\section{Piper Canyon section}

The Piper Canyon section is exposed in low roadcuts along Piper Canyon Road at an elevation of about $310 \mathrm{~m}$ (Figs 1 and 2). The outcrop comprises a medium to dark grey-brown silt; sedimentary structures are not evident. In one of the exposures, a dispersed tephra is preserved which is a compositional match for MSH So (Table 1). The Piper Canyon section is interpreted as representing an environment similar to that of the hydromorphic soil zone in the McFeely Road section. The absence of stratification (other than the tephra horizon) is attributed to bioturbation of sediments. The Piper Canyon section is fossiliferous, containing abundant specimens of the gastropod genera Columella, Striatura, Vallonia, and Succinea (Fig. 3) and rare specimens of an unidentified bivalve mollusc.

\section{AGE AND CORRELATION OF STUDY SECTIONS}

\section{Tephra age discrepancies}

A key element in the interpretation of the study sections is the age of the MSH tephras, on which the age of the Missoula Flood sequence is based. There is considerable uncertainty on this issue; key papers in the ongoing discussion of tephra ages include Mullineaux et al. (1975, 1978), Crandell et al. (1981), Mehringer et al. (1984), Mullineaux (1986), Berger \& Busacca (1995), Mullineaux (1996), Negrini et al. (2000), Clague et al. (2003) and Kuehn et al. (2009). In particular, the ages of the MSH set S ash couplet (So and $\mathrm{Sg}$ ) are critical. The MSH set S tephra in the study sections is a close match with the So tephra (Table 1; SC $=0 \cdot 98$ ). In the following discussions, ages are in thousands of ${ }^{14} \mathrm{C}$ yr BP unless otherwise stated in the text.

According to Mullineaux et al. (1975), the MSH set $\mathrm{S}$ tephras were erupted during a lengthy period of explosive activity that extended from about 18.0 to about $12.0 \mathrm{ka}$. Individual ages of the set $\mathrm{S}$ tephras are less certain; the So and Sg were thought to be about 13.0 kyr (Mullineaux et al., 1978). In a palaeomagnetic study of Missoula Flood slackwater sediments in the Yakima and Walla Walla Valleys, Clague et al. (2003) indicate that the ages of the So and Sg tephras are 13.35 and $14.4 \mathrm{kyr}$, respectively.

Berger \& Busacca (1995) give an age for the set $S$ tephras of $17 \cdot 0$ to $21 \cdot 0 \mathrm{kyr}$ based on thermoluminescence (TL) dating of loess bracketing the tephra layers. This age is considerably older than all recent references to the age of the set $S$ tephras; however, it does not seem to have been accepted widely. The age of 13.35 kyr (Clague et al., 2003) 
for the MSH So tephra is most consistent with the radiocarbon age of fossils and stratigraphy in the study sections.

The MSH set C tephras were erupted over an interval of $36 \cdot 0$ to $>42 \cdot 0 \mathrm{ka}$ (Crandell et al., 1981). According to Berger \& Busacca (1995), the TL age of the MSH Cw is $46 \cdot 0 \pm 6$ to $<75 \cdot 0 \pm 6 \mathrm{kyr}$, based on analysis of bracketing loess; these authors further indicate a TL age of $46 \cdot 0 \pm 5 \mathrm{kyr}$ for siltsized glass from an MSH Cy bed in Oregon and Negrini et al. (2000) report an age of $47 \pm 2 \mathrm{kyr}$ for MSH Cy at Summer Lake, Oregon. The present study will use the age of $47 \pm 2 \mathrm{kyr}$ for the $\mathrm{MSH}$ set C tephra (Negrini et al., 2000) in the Ayer Road section; the interpretation of depositional history is not contingent upon the specific identity of the set $C$ tephra, nor on its precise age.

The Glacier Peak tephra was assigned an age of $11 \cdot 2 \mathrm{kyr}$ (Mehringer et al., 1984). More recent and comprehensive work by Kuehn et al. (2009) gives a revised age for the Glacier Peak tephra of $11.6 \mathrm{kyr}$. This age is consistent with the stratigraphy of the McFeely Road section of this report, in which the Glacier Peak tephra occurs in massive silt, interpreted as loess, stratigraphically above what will subsequently be shown to be Missoula Flood slackwater sediments.

\section{Age and correlation of study sections}

The age of the fossil-bearing outcrops is constrained to the late Pleistocene ( $>47 \cdot 0$ to $9 \cdot 43 \mathrm{ka}$ ) as determined by geochemical characterization of Cascade-sourced tephras exposed in the sections
(Table 1) and AMS radiocarbon dating of fossil material in the McFeely Road and Piper Canyon sections. Correlation of study sections to the pedostratigraphic scheme established by Busacca \& McDonald (1994) and tephra chronology are shown in Figs 2 and 4.

The Ayer Road section contains tephra from Mt St Helens set C (ca. 47·0 ka; Negrini et al., 2000) and So (ca. $13.35 \mathrm{ka}$; Clague et al., 2003). The fossiliferous interval occurs below the set C horizon and the Washtucna and Old Maid Coulee soils (Figs 2 and 4); this interval represents the lower part of loess unit L-2 (Busacca \& McDonald, 1994). The presence of the MSH So tephra in the upper part of the section indicates that at least a part of the L-1 loess is present.

The McFeely Road section contains tephra from MSH So (13.35 kyr; Clague et al., 2003) and Glacier Peak (11.6 kyr; Kuehn et al., 2009). Accelerator mass spectrometry radiocarbon dating of fossil material from McFeely Road establishes the age of the fauna as $12.48 \pm 0.06 \mathrm{kyr}$; specimens taken for dating are from a well-developed soil zone above the So tephra. The So tephra and the fossiliferous part of the section occur about 3 to $4 \mathrm{~m}$ above the base of the exposure; this section spans the boundary between loess units L-2 and L-1 of Busacca \& McDonald (1994). The soil from which the dated fossil specimens are taken postdates the last Missoula Flood. Stratigraphic relationships and ages are shown in Figs 2 and 4.

The Piper Canyon section yielded an AMS radiocarbon age from specimens above the tephra of $9 \cdot 43 \pm 0.05 \mathrm{kyr}$, and is loosely correlative with
Fig. 4. Relationship between loess and pedostratigraphic units, tephra horizons, outburst flood sequences, molluscan faunules and radiocarbon age for outcrops discussed in the text. No scale intended.

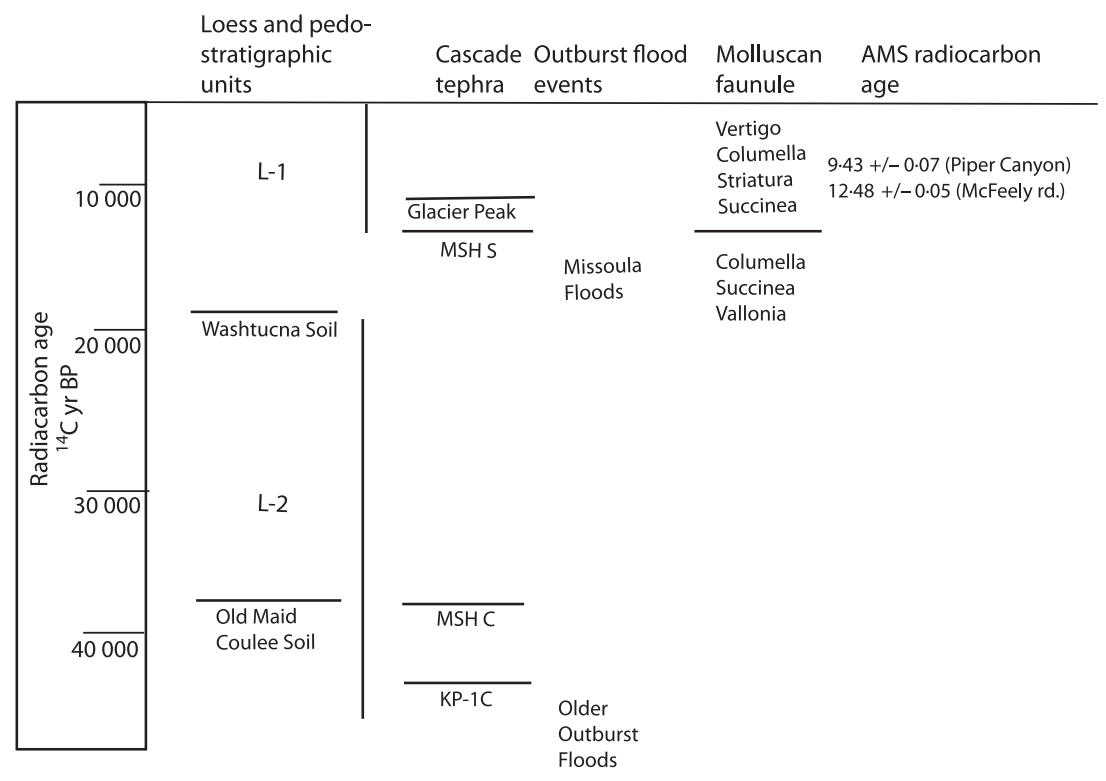


the fossil-bearing interval at McFeely Road. The tephra exposed in the Piper Canyon section is the MSH So based on similarity in sediment type, similar inferred stratigraphic position, tephra glass composition (Table 1) and the radiocarbon age of the fossils associated with the tephra in outcrop.

The Ayer Road, McFeely Road, Donnelly Road and Piper Canyon sections overlap in time and are correlative with sections studied by Busacca et al. (1992) (Figs 2 and 4) representing the L-1 and L-2 loess units. The correlations are significant when viewed in the context of the sedimentological interpretations. The Ayer Road section represents a long period of loess aggradation interrupted at intervals by topographic stability and soil development. In part concurrent with this, the McFeely Road and Piper Canyon sections were accumulating sediment under aqueous conditions.

\section{RELATIONSHIP OF STUDY SECTIONS TO MISSOULA FLOOD DEPOSITS}

The late Pleistocene Missoula Floods resulted from repeated catastrophic failure of an ice dam on Clark's Fork west of Missoula, Montana. During the last-glacial episode of flooding there were as many as 40 individual flood events (Waitt, 1980, 1985). Each flood carried a heavy load of sediment ranging in grain-size from coarse sand to silt; in addition, the flood waters carried sediment-laden ice bergs. Deposits related to the Missoula Floods in the study area are characterized as slackwater facies laid down as floodwaters backed up at the constriction formed by Wallula Gap and backflooded the Pasco Basin and Walla Walla Valley (Fig. 1). The slackwater deposits in the Walla Walla Valley are known as the Touchet Beds (Flint, 1938). Thickness relationships in well-exposed sections of the Touchet Beds suggest that the flood events later in the Missoula Flood sequence were of greater frequency and lesser magnitude than were the earlier floods (Waitt, 1994).

The maximum elevation of flood waters was $381 \mathrm{~m}$ at Wallula Gap (Fig. 1) based on the presence of deposits of cobble and boulder erratics carried by glacial ice, which became stranded on the shoreline as flood water receded (Allen et al., 1986). That elevation represents maximum flood elevation at the point of constriction at Wallula Gap. It is likely that later floods only reached lower elevations (based on the work of Waitt, 1994) more consistent with the elevation of stratified sediments and soils at McFeely Road, Donnelly Road and Piper Canyon.

The precise timing of the Missoula Floods is a subject on which there is still some discussion, and it hinges largely on the age of the MSH So and Sg tephra couplet. Benito \& O'Conner (2003) indicate that several of the Missoula Floods postdate the set S tephras; the Missoula Floods are generally thought to have taken place between about $15 \cdot 0{ }^{14} \mathrm{C} \mathrm{ka}$ and the end of glacial Lake Missoula at about $12 \cdot{ }^{14} \mathrm{C} \mathrm{ka}$. Whatever the age of the latest Missoula flood, it is well-documented that the MSH set S tephras occur at least several beds below the top of the Missoula Flood sequence (Waitt, 1980, 1985).

In the Walla Walla River drainage, valleys tributary to the Walla Walla River were backflooded to elevations consistent with maximum flood elevations at Wallula Gap and elsewhere in the Walla Walla Valley. Exposures of the Touchet Beds in the study area show that the top of the sequence lies at an elevation of less than about $320 \mathrm{~m}$. Floods sufficient to deposit Touchet Beds at these elevations would backflood the McFeely Road, Donnelly Road and Piper Canyon areas to elevations consistent with those of the stratified and soil-bearing units.

\section{Interpretive depositional history: Touchet River Valley and McFeely Road}

The following scenario for deposition of sediments in the McFeely Road, Donnelly Road and Piper Canyon sections is based on the radiocarbon age of the molluscan fauna, geochemical identity and age of preserved tephras, present-day elevations of the outcrops, and the presence of Missoula Flood slackwater deposits along the sides of the Touchet River Valley at elevations similar to the study sections. The series of interpretive cross-sections shown in Fig. 5 diagrammatically represents the evolution of the Touchet River Valley at McFeely Road; a similar evolution is inferred for correlative outcrops at Donnelly Road and Piper Canyon.

Stage 1 (>15.0 ka)

Prior to initiation of the late Wisconsinan Missoula Floods, the Touchet River Valley was floored by alluvium deposited on the floodplain of the ancestral Touchet River. Rocks belonging to the CRBG were exposed in the valley walls. At this stage, there may have been a thin covering of loess on parts of the exposed basalt surface (loess unit L-2 of Busacca \& McDonald, 

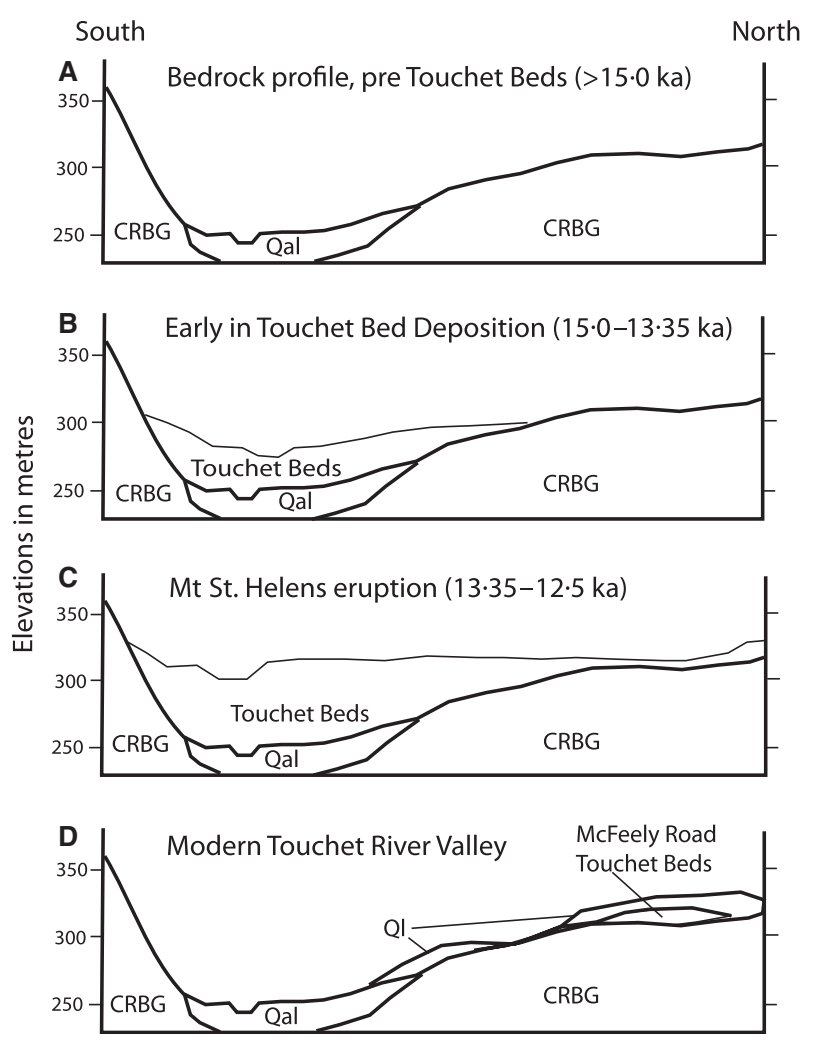

Fig. 5. Evolution of Touchet River Valley and the McFeely Road section during the late Pleistocene. CRBG, Columbia River Basalt Group; Qal, Touchet River alluvium; Ql, Quaternary loess. See text for explanation. Elevation is in metres.

1994), although there is no record of this unit in the McFeely Road exposure. To the west, the Ayer Road outcrop does preserve this older loess unit (Fig. 5A).

\section{Stage 2 (between $15 \cdot 0$ and $13.35 \mathrm{ka}$ )}

At some point of time early in the Missoula Flood sequence, but prior to the MSH So eruption, the valley was partially filled with slackwater sediments. The floods scoured any loess from higher elevation basalt surfaces, and redeposited the sediments as part of the slackwater facies. Subsequent to each event of flooding, normal fluvial processes resumed and the Touchet River regraded its floodplain, redistributing slackwater sediments and downcutting portions of the floodplain. Fluvial activity in the ephemeral stream that periodically occupied the McFeely drainage eroded Missoula Flood sediments deposited at higher elevations. Any loess accumulating during the interflood periods was minimal, as individual flood events were separated by only decades (Waitt, 1985) (Fig. 5B).
Stage $3(13.35$ to $12.5 \mathrm{ka})$

By the time of the eruption of the MSH So tephra, the valley had received a blanket of slackwater sediment that partially covered the McFeely drainage to an elevation of at least $315 \mathrm{~m}$. The Touchet River partially regraded the floodplain, but the extent of the sediment blanket prevented complete removal of Missoula Flood sediment at the highest elevations in the McFeely drainage. Mount St Helens So tephra blanketed the region as a thin but relatively pure layer. The stratified sediment at the base of the McFeely Road section represents the upper limit of deposition during the latest phase of flooding of the Missoula Flood sequence.

The deposition of slackwater sediment far up the McFeely drainage flattened the gradient on the ephemeral stream, and allowed water in the drainage to pond on the irregular surface of the Missoula Flood deposits. Locally, this surface allowed sediment washed from higher elevations to accumulate in topographic lows and keep the surface saturated. Slopewash from exposed basalt surfaces on the McFeely valley walls generated the small-scale, coarse-grained channel-fill deposits in the exposure. Hydromorphic soils formed on the surface of these saturated low spots here, and in the Piper Canyon and Donnelly Road exposures, over the next few thousand years (Fig. 5C).

\section{Stage $4(11 \cdot 6$ to $9 \cdot 43 \mathrm{ka})$}

Subsequent to the final event in the Missoula Flood sequence, erosion of the higher elevations on the valley sides removed much of the accumulated slackwater sediment and the associated soils. This effect was accomplished in large part by regrading of the floodplain by the Touchet River but was aided by stream flow in the McFeely drainage and slopewash processes. The final few Missoula Floods may have played a role in scouring earlier flood deposits from the valley sides. However, it is also possible that the final few Missoula Floods were of insufficient magnitude to flood the valleys to the elevation of the McFeely Road and correlative sections. Removal of the soils and rhythmically deposited sediments (now the McFeely Road, Donnelly Road and Piper Canyon outcrops) was incomplete. After the Missoula Floods, deposition of loess unit L-1 commenced and the region, including the study sections, was covered with a discontinuous blanket of aeolian sediment. Glacier Peak erupted the $11.6 \mathrm{kyr}$ tephra. The Touchet River regraded its floodplain to the current elevation (Fig. 5D). 


\section{THE FAUNA AND ITS POTENTIAL PALAEOECOLOGICAL AND BIOSTR ATIGR APHIC SIGNIFICANCE}

The fauna preserved in the study sections comprises five genera of gastropods previously undocumented from sediments of late Pleistocene age in south-eastern Washington. All taxa are represented by living species elsewhere in the Pacific Northwest and the mid-western USA; fossils of similar species are known from deposits of a similar age in the mid-west (Wayne, 1959; Taft, 1961; Branson, 1980; Karrow et al., 1997). Representative specimens are illustrated in Fig. 3.

Snail faunas provide useful palaeoenvironmental data which, in combination with mammalian fossils and other physical and biological criteria, establish a firmer basis for palaeoenvironmental interpretation of the region during the time period in question. In the Pleistocene of Indiana, species of Columella, Vertigo and Succinea occurring in Wisconsinan and pre-Wisconsinan silts, loess and lake sediment suggest cool-to-cold, moist, open-park conditions (Wayne, 1959). Living specimens of Vertigo in the Washington Cascades are found in close proximity to active glaciers and recently deglaciated valleys at elevations in excess of $1000 \mathrm{~m}$ (Branson, 1980). The fossil specimens from the study sections can be inferred to represent similar conditions of cool-to-cold, moist, open-park habitat. This observation is consistent with inferred climatic conditions in the region as the Cordilleran ice sheet began its most recent advance into Washington about $25.0 \mathrm{ka}$ and the final retreat sometime around 14.0 ka (Clague et al., 1980).

Stratigraphic distribution of the fossil species indicates that there are two faunules present. In the McFeely Road section, occurring beneath the MSH So tephra and representing the lower portion of loess unit L-1, a faunule composed of Vallonia, Columella and Succinea is preserved. Above the So tephra, a faunule composed of Succinea, Striatura, Columella and Vertigo is preserved. Striatura and Vertigo have not been recovered from sediments below the MSH So tephra. In the Piper Canyon section, the fauna above the So tephra is composed of Columella, Striatura and Succinea. Vertigo has not been found. In the Donnelly Road exposure, a single specimen of Striatura has been recovered from the poorly exposed outcrop. Analysis of the snail faunules shows the genera Vertigo and Striatura only occurring above the MSH So tephra, in sediments corresponding to loess unit L-1 of
Busacca \& McDonald (1994), while Vallonia only occurs below the So tephra. The relationship of faunules to pedostratigraphic units, tephras and the study sections is summarized in Fig. 4.

\section{CONCLUSIONS}

Stratigraphic and sedimentological analysis of the study sites indicates that the informally recognized Palouse loess in the southern part of the Columbia Basin comprises a more diverse assemblage of sedimentary facies than has been recognized previously. These facies include aeolian, fluvial and lacustrine sediments and iron-rich soils associated with slackwater deposition by the late Wisconsinan Missoula Floods in distal tributary valleys of the Walla Walla River in southeastern Washington, which were backflooded during the late Pleistocene outburst flood events.

Stratigraphic control in the study sections is provided by the presence of distinctive pedostratigraphic units (Washtucna and Old Maid Coulee soils), geochemical identity of Cascade-sourced tephras (Mount St Helens So, ca 13.35 kyr; set C, ca $47 \cdot 0 \mathrm{kyr}$; and Glacier Peak, ca $11.6 \mathrm{kyr}$ ) and accelerator mass spectrometry radiocarbon dating of snails from exposures at McFeely Road and Piper Canyon (ages 12.48 and 9.43 kyr, respectively). Study sections comprise parts of loess units L-1 and L-2 in the scheme developed by Busacca \& McDonald (1994).

Fossil gastropods collected from late Pleistocene aeolian and fluvio-lacustrine sediments in south-eastern Washington represent the first published report of land snails from the late Pleistocene Palouse loess. The stratigraphic distribution of these fossils is in sediments ranging in age from $>47 \cdot 0$ to $9 \cdot 43 \mathrm{ka}$, within the L-1 and L-2 loess units. The fossils define two distinct faunules; the boundary between them is the Mount St Helens So tephra. Similar species occur in Pleistocene loess and related deposits in the mid-western USA; similar living species are found in alpine and sub-alpine valleys in the Cascade Mountains of Washington. The gastropod fauna suggests conditions of cool-to-cold, moist, open-park conditions for this part of south-eastern Washington for the latest Pleistocene, which is consistent with the presence of continental ice to the north during at least part of the time period represented in the study sections. These faunules, together with the soil and tephra horizons, provide a means for establishing ages and relative stratigraphic positions, as well as palaeoenvironmental 
reconstructions, within the late Quaternary loess of the Pacific Northwest.

The radiocarbon age of the fossil material associated with the Mount St Helens So tephra helps to resolve discrepancies in the reported ages of this tephra in the published literature. Published ages range from as young as 12.0 to as old as $21.0 \mathrm{kyr}$ based on radiocarbon and thermoluminescence dating. This study shows a fossil fauna in the McFeely Road section that is associated closely with, and above, the Mount St Helens So tephra as having an age of 12.48 \pm $0.06 \mathrm{kyr}$. The age of the So tephra (13.35 kyr) as given by Clague et al. (2003) is probably accurate.

\section{ACKNOWLEDGEMENTS}

The authors acknowledge the Sally Ann Abshire Research Scholar Award program of Whitman College and the Whitman College Geology Department, both of which provided funding for this project. We especially thank Franklin Foit of Washington State University for tephra sourcing, BETA Analytic, Inc. for AMS radiocarbon dating of fossil snails, and Katie Laddish and Autumn Ela for some of the sedimentological analysis. Many Whitman College students contributed over the years with on site collecting and discussions of stratigraphy and sedimentology. We also thank anonymous reviewers for many helpful comments and suggestions.

\section{REFERENCES}

Allen, J.E., Burns, M. and Sargent, S. (1986) Cataclysms on the Columbia. Timber Press, Portland, OR, 211 pp.

Benito, G. and O'Conner, J.E. (2003) Number and size of lastglacial Missoula floods in the Columbia River valley between the Pasco Basin, Washington and Portland, Oregon. Geol. Soc. Am. Bull., 115, 624-638.

Berger, G.W. and Busacca, A.J. (1995) Thermoluminescence dating of late Pleistocene loess and tephra from eastern Washington and southern Oregon and implications for eruptive history of Mount St. Helens. J.Geophys. Res., 100:B11, 22361-22374.

Bjornstadt, B.N., Fecht, K.R. and Pluhar, C.J. (2001) Long history of pre-Wisconsin, Ice Age catastrophic floods: evidence from south-eastern Washington state. J. Geol., 109, 695-713.

Borchardt, G.A., Aruscavage, P.J. and Mallard, H.P., Jr (1972) Correlation of the Bishop ash, a Pleistocene marker bed, using instrumental neutron activation analysis. J. Sed. Petrol. 42, 301-307.

Branson, A.B. (1980) Collections of gastropods from the Cascade Mountains of Washington. The Veliger 23, 171-176.
Busacca, A.J. and McDonald, E.V. (1994) Regional sedimentation of late Quaternary loess on the Columbia Plateau: sediment source areas and loess distribution patterns. Wash. Div. of Earth Res. Bull. 80, 181-190.

Busacca, A.J., Nelstead, K.T., McDonald, E.V. and Purser, M.D. (1992) Correlation of distal tephra layers in loess in the Channeled Scabland and Palouse of Washington State. Quatern. Res. 37, 281-303.

Clague, J.J., Armstrong, E. and Matthews, W.H. (1980) Advance of the late Wisconsin Cordilleran ice sheet in Southern British Columbia since 22,000 yr B.P. Quatern. Res. 13, 322-326.

Clague, J.J., Barendregt, R., Enkin, R.J. and Foit, F.F., Jr (2003) Paleomagnetic and tephra evidence for tens of Missoula Floods in southern Washington. Geology 31, 3.

Crandell, D.R., Mullineaux, D.R., Rubin, M., Spiker, E. and Kelly, M.L. (1981) Radiocarbon dates from volcanic deposits at Mount St. Helens, Washington. US Geol. Surv. Open-File Report 81-844.

Duchaufour, P. (1982) Pedology. George Allen and Unwin, London, $448 \mathrm{pp}$.

Flint, R.F. (1938) Origin of the Cheney-Palouse scabland tract. Geol. Soc. Am. Bull. 49, 461-524.

Karrow, P.F., Seymore, K.L., Miller, B.B. and Mirecki, J.E. (1997) Pre-late Wisconsin Pleistocene biota from southeastern Michigan, U.S.A. Palaeogeogr. Palaeoclimatol. Palaeoecol. 133, 81-101.

Kuehn, S.C., Froese, D.G., Carrara, P.E., Foit, F.F., Jr, Pearce, N.J.G. and Rotheisler, P. (2009) Major- and trace-element characterization, expanded distribution, and a new chronology for the latest Pleistocene Glacier Peak tephras in western North America. Quatern. Res. 71, 201-216.

Lindsey, K. (1990) Lithofacies and sedimentology of the Miocene-Pliocene Ringold Formation, Hanford site, southcentral Washington. Northwest Sci. 64, 165-180.

McDonald, E.V. and Busacca, A.J. (1988) Record of pre-late Wisconsin giant floods in the Channeled Scabland interpreted from loess deposits. Geology 16, 728-731.

McDonald, E.V. and Busacca, A.J. (1992) Late Quaternary stratigraphy of loess in the Channeled Scabland and Palouse regions of Washington State. Quatern. Res. 38, 141-156.

Mehringer, P.J., Jr, Sheppard, J.C. and Foit, F.F., Jr (1984) The age of Glacier Peak tephra in west-central Montana. Quatern. Res. 21, 36-41.

Mullineaux, D.R. (1986) Summary of pre-1980 tephra-fall deposits erupted from Mount St. Helens, Washington State, U.S.A. Bull. Volcanol. 48, 17-26.

Mullineaux, D.R. (1996) Pre-1980 tephra fall deposits from Mount St. Helens, Washington. US Geol. Surv. Prof. Pap., 1563, 19.

Mullineaux, D.R., Hyde, J.H. and Rubin, M. (1975) Widespread late glacial and postglacial tephra deposits from Mount St. Helens volcano, Washington. US Geol. Surv. J. Res. 3, 329-335.

Mullineaux, D.R., Wilcox, R.E., Ebaugh, W.F., Fryxell, R. and Rubin, M. (1978) Age of the last major scabland flood of the Columbia Plateau in eastern Washington. Quatern. Res. 10, 171-180.

Negrini, R.M., Erbes, D.B., Faber, K., Herrera, A.M., Roberts, A.P., Cohen, A., Palacios-Fest, M., Wigland, P. and Foit, F. (2000) A paleoclimate record for the last 250,000 years from Summer Lake, Oregon, USA: age control and magnetic lake level proxies. J. Paleolimnol. 24, 125-149.

Rensberger, J.M., Barnosky, A.D. and Spencer, P.K. (1984) Geology and Paleontology of a Pleistocene-to-Holocene 
Loess Succession, Benton County, Washington. Eastern Wash. Univ. Rep. Archaeol. Hist., 100-39, 102.

Smith, G.A. (1988) Sedimentology of proximal to distal volcaniclastics dispersed across an active foldbelt; Ellensburg Formation (late Miocene), central Washington. Sedimentology 35, 953-977.

Spencer, P.K. (1989) A small mammal fauna from the Touchet Beds of Walla Walla County, Washington: support for the multiple-flood hypothesis. Northwest Sci. 63, 167-174.

Spencer, P.K. and Jaffee, M. (2002) Pre-late Wisconsinan glacial outburst floods in southeastern Washington: the indirect record. Wash. Geol. 30: 1/2, 9-16.

Taft, C. (1961) The shell-bearing land snails of Ohio. Bull. Ohio Biol. Surv. 1, 105.

Waitt, R.B. (1980) About forty last-glacial jokuhlaups through southern Washington. J. Geol. 88, 653-679.
Waitt, R.B. (1985) Case for periodic, colossal jokulhlaups from Pleistocene glacial Lake Missoula. Geol. Soc. Am. Bull. 96, 1271-1286.

Waitt, R.B. (1994) Scores of gigantic, successively smaller Lake Missoula floods through Channeled Scabland and Columbia Valley. In: Geological Field Trips in the Pacific Northwest (Eds D.A. Swanson and R.A. Haggerud), Geol. Soc. Am. Annu. Meeting, Boulder, Colorado, v.1, p. 1K-1-88.

Wayne, W.J. (1959) Stratigraphic distribution of Pleistocene land snails in Indiana. Sterkiana 1, 9-18.

Manuscript received 11 March 2009; revision accepted 22 May 2009 